\title{
Termites are associated with external species-specific bacterial communities
}

\author{
Patrik Soukup ${ }^{1}$, Tomas Vetrovsky ${ }^{2}$, Petr Stiblik ${ }^{1}$, Katerina Votypkova ${ }^{1}$, Amrita \\ Chakraborty $^{1}$, David Sillam-Dusses ${ }^{3}$, Miroslav Kolarik ${ }^{2}$, Iñaki Odriozola ${ }^{4}$, Nathan Lo ${ }^{5}$, \\ Petr Baldrian $^{6}$, Jan Sobotnik ${ }^{1}$, and Thomas Bourguignon ${ }^{7}$ \\ ${ }^{1}$ Czech University of Life Sciences Prague \\ ${ }^{2}$ Institute of Microbiology Czech Academy of Sciences Laboratory of Environmental \\ Microbiology \\ ${ }^{3}$ Sorbonne North Paris University \\ ${ }^{4}$ Institute of Microbiology Czech Academy of Sciences \\ ${ }^{5}$ Affiliation not available \\ ${ }^{6}$ Institute of Microbiology ASCR \\ ${ }^{7}$ Okinawa Institute of Science and Technology Graduate University
}

April 28, 2020

\begin{abstract}
All termites have established a wide range of associations with symbiotic microbes in their guts. Some termite species are also associated with microbes that grow in their nests, but the prevalence of these associations remains largely unknown. Here, we studied the bacterial communities associated with the termites and galleries of three wood-feeding termite species using $16 \mathrm{~S}$ rRNA amplicon sequencing. We found that the composition of bacterial communities differs among termite bodies, termite galleries, and control wood fragments devoid of termite activities, in a species-specific manner. Termite galleries were enriched in bacterial OTUs belonging to Rhizobiales and Actinobacteria, which were often shared by several termite species. The abundance of several bacterial OTUs, generally belonging to genera known to include animal pathogens, was depleted in termite galleries. Our results demonstrate that termites not only harbour unique bacterial communities inside their guts, but also shape the communities colonizing their nests and galleries.
\end{abstract}

\section{Introduction}

Termites harbour diverse communities of microbes in their hindguts that participate in lignocellulose digestion, nitrogen metabolism, and other functions (reviewed by Bignell 2011; Hongoh 2011; Brune 2014; Brune \& Dietrich 2015). Gut microbes have been coevolving along with termites for tens of millions of years, and many species are found nowhere else than in the termite gut (Bourguignon et al. 2018). Consequently, termite gut microbial communities are unique in terms of composition, differing substantially among species (Dietrich et al. 2014; Otani et al. 2014; Mikaelyan et al. 2015) and differing from the communities present in soil, wood, and termite nest material (Makonde et al. 2015; Manjula et al. 2016).

In addition to the microbes present in their guts, some termite species are known to partner with mutualistic symbionts that grow outside of bodies, which we define here as 'ectosymbionts' (this term is also used in a different sense, to describe symbionts that attach to the exterior of protozoan symbionts found in termite guts; Noda et al. 2003). All species of Macrotermitinae cultivate the macroscopic fungusTermitomyces within their nests (Rouland-Lefèvre 2000).Termitomyces species are only associated with fungus-growing 
termites (Krishna et al. 2013; Mossebo et al. 2017) and, due to their prevailing horizontal transmission, have undergone a number of switches between species in this group (Aanen et al. 2002; Nobre et al. 2011). Another putative example of nutritional ectosymbiosis is that between Sphaerotermes sphaerothorax, the only described species of Sphaerotermitinae, and bacteria of unknown taxonomic composition that are found inside specialized combs forming the core of S. sphaerothorax nests (Garnier-Sillam et al. , 1989). No other nutritional ectosymbionts are known to be associated with termites.

Termites have also evolved defensive mutualisms with ectosymbiotic microbes. Termites primarily feed on wood, sometimes in an advanced stage of decomposition, or on soil (Donovan et al. 2001; Bourguignon et al. 2011), both of which are inhabited by a great deal of microbes. In addition, termites are social insects that live in densely populated nests, potentially facilitating the transmission of diseases (Rosengaus et al. 2011). Some termites have evolved an association with Streptomyces bacteria helping them to defend against pathogens (Visser et al. 2012; Chouvenc et al.2013, 2018). Ectosymbiotic Streptomyces are not specific to termites, but are recruited from the soil surrounding the faecal nest, and become abundant in termitemanaged environments (Chouvenc et al. 2018).

The diversity of microbes externally associated with termites is unlikely to be limited to a handful of ectosymbionts with nutritional and defensive functions. Termite activities are expected to have a significant effect on composition of surrounding microbial communities. For example, termites produce antifungal and antimicrobial compounds that they release from their salivary glands and faecal pellets (Bulmeret al. 2009, 2010, 2012; Rosengaus et al. 1998; Heet al . 2018). Saliva and faecal fluids are used as building material (Noirot \& Darlington 2000), and their biocide properties prevent microbial colonization of the nest and galleries, which remain free of visible fungal overgrowths (Chouvenc et al. 2013; Rosengaus et al. 2013). Termites also tunnel into wood, and move vast amounts of soil (Wood \& Sands 1976; Ulyshen \& Wagner 2013; Ulyshen et al. 2014), facilitating the spread of microbes and fungi (Ulyshen 2016). Lastly, termites maintain microclimatic conditions within their nests and galleries (Noirot \& Darlington 2000), potentially favouring the growth of certain microbes while supressing that of others. In consequence, the microbial communities colonizing termite nests and galleries are expected to differ from that of termite-free environments.

Several studies have shown that the bacterial communities thriving on termite-modified materials differ from that of soil or wood (Jouquetet al. 2005, 2011; Fall et al. 2004, 2007; Kirker et al. 2012). However, these studies provided only limited insight into the composition of bacterial communities, and no insight into the specificity of termite-bacteria associations. The few studies based on high-throughput sequencing approaches, which allow taxonomic identification of bacteria, provided contradictory results, either suggesting that microbial communities of termite nests are similar to that of surrounding soil (Makonde et al. 2015), or showing that the fungal combs of each Macrotermitinae species host unique bacterial communities (Otani et al. 2016).

In this study, we used high-throughput sequencing of $16 \mathrm{~S}$ rRNA gene fragments to compare the bacterial communities of termite bodies, termite galleries, and control wood samples devoid of termite activities. We worked on three wood-feeding termite species abundant in French Guiana forests: Coptotermes testaceus , Heterotermes tenuis (both Rhinotermitidae) and Nasutitermes octopilis(Termitidae: Nasutitermitinae). Using this dataset, we determined the influence of termites on the surrounding bacterial communities, and identified the bacterial lineages depressed by termites, or externally associated with termites.

\section{Material \& Methods}

\section{Study site and sampling}

The fieldwork took place in November 2014 in the Nouragues Nature reserve (French Guiana; N 0405', W $\left.52^{\circ} 41^{\prime}\right)$. We collected samples of three species: Coptotermes testaceus Linnaeus, 1758 , Heterotermes tenuis Hagen, 1858, and Nasutitermes octopilis Banks, 1918. Upon encounter of one of these species, we collected one series of samples, all collected in the same wood log, consisting of three termite samples (between 10 and 15 workers each), together with three samples of their feeding substrates (approx. $1 \mathrm{~cm}^{3}$ piece of wood containing thin galleries), and three control samples (approx. $1 \mathrm{~cm}^{3}$ of wood at least $10 \mathrm{~cm}$ away from the closest termite galleries). Sample replicates were distant by more than $1 \mathrm{~m}$. Occasionally, for small logs, only 
two samples of each type were collected. All samples were preserved in RNAlater $\AA$, stored at $-20{ }^{\circ} \mathrm{C}$ within 8 hours following collection, and shipped to Prague where they were stored at $-80{ }^{\circ} \mathrm{C}$ until DNA extraction.

\section{DNA extraction and PCR amplification}

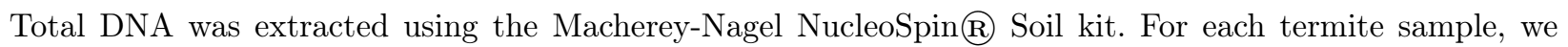
homogenized the bodies of up to ten workers using two sterile steel beads ( $3 \mathrm{~mm}$ diameter) and a Mixer Mill MM 400 set on 30 swings per second for two minutes. We carried out extraction as explained by the manufacturer protocol, except for the lysis step that was shortened to 2 min of vortexing. Wood samples were placed in a sterile $2 \mathrm{~mL}$ tube, frozen in liquid nitrogen, mechanically crushed with five sterile steel beads for 1 min at 30 swings per second, and grinded with a Mixer mill Retsch MM 400 for 10 minutes. Following the first grinding step, we added $550 \mu \mathrm{L}$ of SL2 extraction buffer to the homogenized material and repeated the grinding with the same settings. The lysis by vortexing was extended to $10 \mathrm{~min}$, and precipitation of contaminants was carried out with $100 \mu \mathrm{L}$ of SL3 buffer. Lysate was filtered with $650 \mu \mathrm{L}$ of supernatant. Silica membrane was dried for 3 minutes in centrifuge. Finally, we added $50 \mu \mathrm{L}$ of SE buffer to the silica membrane and centrifuged for $45 \mathrm{sec}$ to elude the DNA. Each sample was handled with flame-sterilized tweezers.

PCR reactions were performed using the Thermo Scientific DyNAzyme II DNA Polymerase kit. We used the universal primers $515 \mathrm{~F}$ and $806 \mathrm{R}$ targeting the V4 region of the $16 \mathrm{~S}$ rRNA gene (Caporaso et al. 2011), combined with an original combination of index reads. The PCR reactions contained $2.5 \mu \mathrm{L}$ of $10 \times$ buffer for DyNAzyme II DNA Polymerase, $0.75 \mu \mathrm{L}$ of BSA $(20 \mathrm{mg} / \mathrm{mL}), 1 \mu \mathrm{L}$ of each primer $(0.01 \mathrm{mM}), 0.5 \mu \mathrm{L}$ of PCR Nucleotide Mix (10 mM each), $0.75 \mu \mathrm{L}$ of polymerase (2 U/ $\mu \mathrm{L}$ DyNAzyme II DNA polymerase), and $1 \mu \mathrm{L}$ of template DNA. PCR reactions were performed using an Eppendorf Mastercycler $\mathbb{R}$ (Eppendorf AG, Hamburg, Germany) nexus cycler, with the following settings: initial denaturation at $94{ }^{\circ} \mathrm{C}$ for 3 min, 30 cycles of $94{ }^{\circ} \mathrm{C}$ for $45 \mathrm{sec}, 50{ }^{\circ} \mathrm{C}$ for $1 \mathrm{~min}, 72{ }^{\circ} \mathrm{C}$ for $45 \mathrm{sec}$, and a final extension step at $72{ }^{\circ} \mathrm{C}$ for 10 min. We carried out three independent PCR amplifications for each sample, combined the three replicates, and cleaned them using the MinElute PCR Purification Kit (QiagenGmbH, Hilden, Germany). Pooled PCR products were mixed in equimolar concentration and paired-end-sequenced with an Illumina MiSeq sequencer (Illumina Inc., USA) using the V2 chemistry to produce 250 bp paired-end reads. Sequence data are deposited in MG-RAST under accession numbers Accession number will be provided upon acceptance of the paper.

\section{Data filtering}

Raw paired-end reads were joined using fastq-join (Aronesty 2011), and demultiplexed, filtered and trimmed using SEED v 2.1 (Větrovský et al. 2018). Sequences with mean Phred quality score $<30$, so well as sequences with mismatches in barcodes, were discarded. We also discarded all bacterial sequences shorter than $200 \mathrm{bp}$ or longer than $350 \mathrm{bp}$. A total of 5,863,706 bacterial sequences were obtained after initial quality-filtering.

\section{OTU clustering and classification}

Sequences were clustered into operational taxonomic units (OTUs) (3\% sequence dissimilarity) using UPARSE implemented in USEARCH version 8.1.1861 (Edgar 2013). Chimeric sequences were identified during clustering to OTUs using UPARSE algorithm, and a total of 526,949 sequences were excluded from downstream analyses. To reduce the influence of contaminations and to minimize the effect of barcode hopping (Thomas et al. 2017), all OTUs with less than five reads were discarded. We also used previous Illumina run data to estimate the number of reads that potentially hopped among samples for all OTUs and removed those reads.

The most abundant sequence from each OTU was used as a representative sequence for taxonomic classification. Representative sequences were classified with the RDP classifier from the RDPTools software version 2.0.2 using the 16SrRNA reference database (Wang et al. 2007). Classification was verified using RDP Release 11 Update 5, accessed on September 302016 (Cole et al. 2014), that provided the closest BLAST hit for each OTU. We used rrnDB version 5.4 (Stoddard et al. 2015) to estimate the relative abundance of each 
OTU, considering the variable number of $16 \mathrm{~S}$ copies per bacterial genome, as explained in Větrovský \& Baldrian (2013).

\section{Comparison of bacterial communities in termite bodies, termite galleries, and wood controls}

To test whether bacterial community composition differs among termite bodies, termite galleries, and wood controls, we performed PERMANOVA (Anderson 2001) using the adonis function from the R package vegan (Oksanen et al. 2007). The response matrix was calculated using the Euclidian distance on Hellingertransformed bacterial composition, which resulted in Hellinger distance matrix (Legendre \& Gallagher 2001). We used sample type (bodies, gallery and wood control) as the explanatory variable. Since samples were collected in series of dependent triplets (or sometimes doublets) coming from a single log, with each triplet comprising three dependent samples (one termite-bodies sample, one gallery sample, and one wood control sample) collected nearby each other, the permutations were constrained to occur among samples of the same triplets, which were used as blocking factor. As such, we used the formula "termite-species*sample-type" and the strata was set to "data\$triplets". We compared termite species and sample types (bodies, gallery or wood control) using pairwise PERMANOVA implemented in the pairwiseAdonis R package (Martinez Arbizu 2017). We used Bonferroni corrections to adjust p-values. Significance was assessed using 99,999 permutations.

We visualized the dataset using non-metric multidimensional scaling (NMDS) implemented with the metaMDS function of the R package vegan (Oksanen et al. 2007). NMDS analysis was carried out using community data regressed against logs and triplets. This procedure removed the effect of spatial variability inherent to the experimental design.

\section{Identification of termite-associated bacteria}

To identify the bacterial OTUs contributing to the separation between termite bodies, termite galleries and wood controls, we used partial redundancy analysis (partial RDA) (Legendre \& Legendre 2012). Each termite species was considered separately. For each RDA, we used Hellinger-transformed bacterial OTU composition as response matrix, and sample type as fixed explanatory factor. The effects of triplets and wood logs were removed by using logs and triplets as conditioning factors in the partial RDA (see Legendre \& Legendre 2012). We focused our efforts on the identification of the main bacterial OTUs and considered those belonging to the $0.25^{\text {th }}$ and $99.75^{\text {th }}$ percentiles. Identified OTUs were classified in one of the following three categories: bodies-associated bacteria (OTUs predominantly found in termite gut), gallery-associated bacteria (OTUs predominantly found in termite galleries), and gallery-depleted bacteria (OTUs predominantly found in control wood samples). Note that generalist OTUs, showing a random distribution pattern, with no preference for termite bodies, termite galleries or control wood samples, are not considered further in this paper.

\section{Results}

Comparison of bacterial communities in termite bodies, termite galleries, and termite-free wood controls

After quality-filtering and removal of chimeras, we obtained an average of 20,685 sequences of the V4 region of the bacterial $16 \mathrm{~S}$ rRNA gene for each of the 258 samples. $16 \mathrm{~S}$ sequences were clustered into 4864 OTUs ( $3 \%$ sequence dissimilarity) represented by more than five sequences.

The PERMANOVA analysis yielded significant differences among groups $\left(\mathrm{F}=22.33, \mathrm{p}<10^{-6}\right)$, including significant differences among termite species $\left(\mathrm{F}=14.773, \mathrm{r}^{2}=0.075, \mathrm{p}<10^{-5}\right)$ and among sample types (bodies, galleries and control wood) $\left(\mathrm{F}=34.636, \mathrm{r}^{2}=0.175, \mathrm{p}<10^{-5}\right)$. Figure 1 shows the NMDS plot calculated for all samples, and represents the bacterial communities of C. testaceus, H. tenuis, and $N$. octopilis bodies as three disjunct clusters. Termite galleries, as well as wood controls, also clustered by termite species, although these clusters were more diffuse and largely overlapped. Pairwise PERMANOVA indicated that the bacterial communities associated with C. testaceus, H. tenuis, and N. octopilis bodies significantly differed from each other (Table 1). Similarly, the bacterial communities of termite galleries significantly differed among termite species, and significantly differed from the corresponding wood controls 
in the case of $C$. testaceus and $N$. octopilis, but not in the case of $H$. tenuis, for which a Bonferroni correction made the comparison only marginally significant (Table 1). Bacterial communities from bodies of $C$. testaceus , H. tenuis, and $N$. octopilis significantly differed from communities colonizing termite galleries and wood controls in all cases (Table 1). Finally, we found no significant difference among wood controls associated with $C$. testaceus, H. tenuis, and N. octopilis (Table 1).

\section{Identification of termite-associated bacteria}

We carried out RDA and considered OTUs from the $0.25^{\text {th }}$ and $99.75^{\text {th }}$ percentiles (Fig. 2). With this approach, we identified 97 bacterial OTUs associated with termites, or depressed by termites, of which many were independently identified for two or three of the studied termite species (Table S1). Of the 47 bacterial OTUs detected to have non-random associations with C. testaceus (Fig. 2A), 14 OTUs were bodies-associated bacteria and made up $68.1 \%$ of the bacterial community of $C$. testaceus bodies, 18 OTUs were enriched in termite galleries, making up $28.3 \%$ of the bacterial $16 \mathrm{~S}$ sequences in termite galleries and $14.2 \%$ of the bacterial 16S sequences in wood controls, and 15 OTUs were depressed by C. testaceus, making up $24.8 \%$ and $3.2 \%$ of the bacterial $16 \mathrm{~S}$ sequences in wood controls and termite galleries, respectively. H. tenuis and $N$. octopilis provided similar results. Of the 48 bacterial OTUs considered for $H$. tenuis (Fig. 2B), 15 OTUs were bodies-associated bacteria and made up $80.8 \%$ of $16 \mathrm{~S}$ sequences of $H$. tenuis bodies, 17 OTUs were gallery-associated bacteria, making up $27.7 \%$ of the bacterial community of termite galleries and $11.3 \%$ of the bacterial community of wood controls, and 16 OTUs were depressed by H. tenuis, making up 24.7\% and $6.7 \%$ of the $16 \mathrm{~S}$ sequences of the control and gallery samples, respectively. Lastly, of the 45 bacterial OTUs considered for $N$. octopilis (Fig. 2C), 15 were bodies-associated bacteria and made up $60.3 \%$ of the termite bacterial community, 15 OTUs were gallery-associated bacteria and made up $25.6 \%$ of the bacterial community of $N$. octopilis galleries and $9.2 \%$ of the bacterial community of wood controls, and 15 OTUs were depressed by $N$. octopilis and made up $34.9 \%$ of the bacterial $16 \mathrm{~S}$ sequences of wood control samples and $1.4 \%$ of the bacterial $16 \mathrm{~S}$ sequences of $N$. octopilis galleries (Table $\mathrm{S} 1$ ).

\section{Discussion}

In this study, we sequenced the bacterial communities associated with three termite species, C. testaceus , $H$. tenuis, and $N$. octopilis. We demonstrated that the composition of bacterial communities differs among termite bodies, termite galleries, and wood controls devoid of visible termite activities, in a species-specific manner. We also identified 97 abundant bacterial OTUs that are predominantly associated with termite bodies (referred to as bodies-associated bacteria), termite galleries (referred to as gallery-associated bacteria), or control wood samples (referred to as gallery-depleted bacteria). Consequently, our results show that termites not only shape the bacterial communities inside their gut (Dietrichet al. 2014, Otani et al. 2014, Mikaelyan et al.2015), but also those in their environment.

The most distinctive bacterial communities are those of termite bodies, which markedly differ among the three studied termite species, and differ from the bacterial communities of wood controls and termite galleries. These results are in line with previous studies that pointed out the distinctiveness of termite bacterial communities, and the presence in termite guts of many bacterial gut symbionts found nowhere else in nature (Dietrich et al. 2014; Mikaelyan et al.2015; Bourguignon et al. 2018). In addition, we independently identified 14-15 bodies-associated bacterial OTUs for each of the three termite species. These OTUs made up 60.3$80.8 \%$ of the total bacterial $16 \mathrm{~S}$ sequences, and were, in most cases, known to be associated with termite guts. For example, we found that Candidatus Azobacteroides and Candidatus Armantifilum, two bacterial lineages known to be associated with termite gut protists (Hongohet al. 2008; Desai et al. 2010), were the dominant gut symbiotic OTUs in C. testaceus ; Candidatus Azobacteroides was also the dominant gut symbiotic OTU in $H$. tenuis. In $N$. octopilis, the dominant gut symbiotic OTUs were assigned toSpirochaeta (Spirochaete) and Fibrobacter (Fibrobacteres) genera. BLAST searches showed that our 16S sequences from these two genera corresponded to Treponema and Fibrobacter sequences previously found in the gut of other species of Nasutitermes(Kohler et al. 2012; Mikaelyan et al. 2014).

We found that the bacterial communities associated with termite galleries are specific to termite species, and 
differ from that of termite bodies and wood controls. These results concur with previous studies that found that bacterial communities associated with nests differ from surrounding soil and wood samples (Jouquet et al.2005, 2011; Fall et al. 2007, Kirker et al. 2012, Otaniet al. 2014). Exclusion experiments have also shown that termites influence the bacterial communities in wood pieces (Ulyshen 2016). Importantly, our results show that the differences between galleries of different termite species and wood control samples are subtler than that found for gut bacterial communities, suggesting that the gallery-associated bacteria are loosely associated with termites.

The identification of the main gallery-associated bacterial OTUs confirmed their loose association with termites. We independently identified 15-18 bacterial OTUs classified as gallery-associated bacteria for each of the three termite species. These OTUs made up 25.6-28.3\% of the $16 \mathrm{~S}$ sequences of termite galleries. However, on the contrary to bodies-associated bacterial OTUs, many gallery-associated bacterial OTUs were shared among termite species, and out of 28 OTUs identified as gallery-associated bacteria, eight were shared by all three termite species, and six were shared by two termite species. In addition, gallery-associated bacterial OTUs were also present in wood controls, albeit in significantly lower abundances (only 9.2-14.3\% of the $16 \mathrm{~S}$ sequences). These results indicate that termite gallery-associated bacteria are recruited from the surrounding environment, as has been shown for Coptotermes formosanus and its ectosymbiotic Streptomyces (Chouvenc et al. 2018).

The gallery-associated bacterial OTUs identified in this study mostly belonged to Proteobacteria and Actinobacteria, which are known to dominate the nest bacterial communities of several Termitidae species (Hellemans et al. 2019). A total of 18 OTUs belonged to Proteobacteria, including seven OTUs assigned to Rhizobiales, five of which were identified as gallery-associated bacteria for the three termite species investigated in this study. Many Rhizobiales are able to fix atmospheric nitrogen and have developed symbiotic associations with plant roots (Van Rhijn \& Vanderleyden, 1995). Their abundance in termite galleries suggests they might be a source of nitrogen for termites, possibly supplementing the nitrogen-poor termite diet, wood. We also identified four gallery-associated bacterial OTUs belonging to Actinobacteria, but none of them belonged to Streptomyces . Therefore, unlike previously found for C. formosanus (Chouvencet al. 2013, 2018), Streptomyces did not appear to be an important gallery-associated bacteria of C. testaceus, H. tenuis and N. octopilis .

Several bacterial OTUs were depressed in termite galleries. The 15-16 gallery-depleted bacterial OTUs we identified for each termite species made up 24.7-34.9\% of the $16 \mathrm{~S}$ sequences in control wood samples, but only $1.4-6.7 \%$ of the $16 \mathrm{~S}$ sequences in termite galleries. These results are indicative of the ability of termites to prevent the growth of undesired microbes in their direct environment, possibly through the production of antimicrobial and antifungal compounds, as it has been shown in several termite species (Chouvenc et al. 2013; Rosengauset al. 2013). Ectosymbionts of termites are also known to produce antimicrobial compounds (Visser et al. 2012; Chouvenc et al. 2013), and it is possible that some of the gallery-associated bacteria we identified have this function. Finally, the microclimatic conditions of termite galleries might also play a role in shaping bacterial communities, and depress the abundance of gallery-depleted bacteria.

As is the case for gallery-associated bacteria, a large fraction of the 27 gallery-depleted bacterial OTUs were identified as depressed for more than one termite species, including five gallery-depleted bacterial OTUs depressed by the three studied termite species and nine gallery-depleted bacterial OTUs depressed by two of the three studied termite species. This suggests that gallery-depleted bacterial OTUs are selectively excluded from the community. Interestingly, many of the gallery-depleted bacterial OTUs belong to genera that are known to include animal pathogens, at least on a facultative basis. This includes, among others, OTUs belonging to the genera Bacillus , Clostridium, Corynebacterium and Staphylococcus, all of which might represent a potential threat to termite colonies. In a homologous manner, fungus-growing termites actively depress fungi pathogens, including Pseudoxylaria, from their Termitomyces fungus garden (Shinzato et al. 2005, Visser et al. 2012). Our results show that termites are not only able to shape the microbial communities inside their nests, but also that in their foraging areas.

\section{Acknowledgments}


We thank the staff of the Nouragues Research Field Station (CNRS, French Guiana) for logistic help during field work. We also thank Olivier Delattre for his help during field sampling. This work was financially supported by the Czech Science Foundation (Project No. GAČR 16-05318S), the project EVA4.0 (CZ.02.1.01/0.0/0.0/16_019/0000803), the Internal Grant Agency of Faculty of Tropical AgriSciences (No. 20195006), and by a Nouragues travel grant "Investissement d'Avenir" from the Agence Nationale de la Recherche.

\section{References}

Aanen, D.K., Eggleton, P., Rouland-Lefèvre, C., Guldberg-Frøslev, T., Rosendahl, S. \& Boomsma, J.J. (2002). The evolution of fungus-growing termites and their mutualistic fungal symbionts. Proc. Natl. Acad. Sci. USA , 99, 14887-14892.

Anderson, M.J. (2001). A new method for non-parametric multivariate analysis of variance. Austral Ecol. , $26,32-46$.

Aronesty, E. (2011). Command-line tools for processing biological sequencing data ea-utils.

Bignell, D.E. (2011). Morphology, physiology, biochemistry and functional design of the termite gut: an evolutionary wonderland. In:Termites: Evolution, Sociality, Symbioses, Ecology (eds. Abe, T., Bignell, D.E. \& Higashi, M.). Kluwer Academic Publishers, Dordrecht, The Netherlands, pp. 375-412.

Bourguignon, T., Lo, N., Dietrich, C., Šobotník, J., Sidek, S., Roisin, Y., et al. (2018). Rampant host switching shaped the termite gut microbiome. Curr. Biol. , 28, 649-654.

Bourguignon, T., Šobotník, J., Lepoint, G., Martin, J.M., Hardy, O.J., Dejean, A., et al. (2011). Feeding ecology and phylogenetic structure of a complex neotropical termite assemblage, revealed by nitrogen stable isotope ratios. Ecol. Entomol., 36, 261-269.

Brune, A. (2014). Symbiotic digestion of lignocellulose in termite guts.Nat. Rev. Microbiol., 12, 168-180.

Brune, A. \& Dietrich, C. (2015). The gut microbiota of termites: digesting the diversity in the light of ecology and evolution.Annu. Rev. Microbiol. , 69, 145-166.

Bulmer, M.S., Lay, F. \& Hamilton, C. (2010). Adaptive evolution in subterranean termite antifungal peptides. Insect Mol. Biol., 19, 669-674.

Bulmer, M.S., Bachelet, I., Raman, R., Rosengaus, R.B. \& Sasisekharan, R. (2009). Targeting an antimicrobial effector function in insect immunity as a pest control strategy. Proc. Natl. Acad. Sci. , 106, 12652-12657.

Bulmer, M.S., Denier, D., Velenovsky, J. \& Hamilton, C. (2012). A common antifungal defense strategy in Cryptocercus woodroaches and termites. Insectes Soc. , 59, 469-478.

Caporaso, J.G., Lauber, C.L., Walters, W.A., Berg-Lyons, D., Lozupone, C.A., Turnbaugh, P.J., et al. (2011). Global patterns of $16 \mathrm{~S}$ rRNA diversity at a depth of millions of sequences per sample. Proc. Natl. Acad. Sci. , 108, 4516-4522.

Chouvenc, T., Elliott, M.L., Šobotník, J., Efstathion, C.A. \& Su, N.Y. (2018). The termite fecal nest: a framework for the opportunistic acquisition of beneficial soil Streptomyces (Actinomycetales: Streptomycetaceae). Environ. Entomol. , 47, 1431-1439.

Chouvenc, T., Efstathion, C.A., Elliott, M.L. \& Su, N.Y. (2013). Extended disease resistance emerging from the faecal nest of a subterranean termite extended disease resistance emerging from the faecal nest of a subterranean termite. Proc. R. Soc. B-Biological Sci., 280, 20131885.

Cole, J.R., Wang, Q., Fish, J.A., Chai, B., Mcgarrell, D.M., Sun, Y.,et al. (2014). Ribosomal database project: data and tools for high throughput rRNA analysis. Nucleic Acids Res., 42, D633-D642. 
Desai, M.S., Strassert, J.F.H., Meuser, K., Hertel, H., Ikeda-Ohtsubo, W., Radek, R., et al. (2010). Strict cospeciation of devescovinid flagellates and Bacteroidales ectosymbionts in the gut of dry-wood termites (Kalotermitidae). Environ. Microbiol. , 12, 2120-2132.

Dietrich, C., Köhler, T. \& Brune, A. (2014). The cockroach origin of the termite gut microbiota: patterns in bacterial community structure reflect major evolutionary events. Appl. Environ. Microbiol. , 80, 2261-2269.

Donovan, S.E., Eggleton, P. \& Bignell, D.E. (2001). Gut content analysis and a new feeding group classification of termites. Ecol. Entomol. , 26, 356-366.

Edgar, G.C. (2013). UPARSE: highly accurate OTU sequences from microbial amplicon reads. Nat. Methods , 10, 996-998.

Fall, S., Nazaret, S., Chotte, J.L. \& Brauman, A. (2004). Bacterial density and community structure associated with aggregate size fractions of soil-feeding termite mounds. Microb. Ecol. , 48, 191-199.

Fall, S., Ndiaye, F., Assigbetse, K., Aragno, M., Chotte, J.L. \& Brauman, A. (2007). Differences between bacterial communities in the gut of a soil-feeding termite (Cubitermes niokoloensis) and its mounds. Appl. Environ. Microbiol. , 73, 5199-5208.

Garnier-Sillam, E., Toutain, F., Villemin, G. \& Renoux, J. (1989). Etudes préliminaires des meules originales du termite xylophageSphaerotermes sphaerothorax (Sjostedt). Insectes Soc. , 36, 293-312.

He, S., Johnston, P.R., Kuropka, B., Lokatis, S., Weise, C., Plarre, R., Kunte, H.-J., McMahon, D.P. (2018) Termite soldiers contribute to social immunity by synthesizing potent oral secretions. Insect Mol. Biol ., 27, $564-576$.

Hellemans, S., Marynowska, M., Drouet, T., Lepoint, G., Fournier, D., Calusinska, M., et al. (2019). Nest composition, stable isotope ratios and microbiota unravel the feeding behaviour of an inquiline termite. Oecologia , 191, 541-553.

Hongoh, Y. (2011). Toward the functional analysis of uncultivable, symbiotic microorganisms in the termite gut. Cell. Mol. Life Sci. , 68, 1311-1325.

Hongoh, Y., Sharma, V.K., Prakash, T., Noda, S., Toh, H., Taylor, T.D.,et al. (2008). Genome of an endosymbiont within protist cells in termite gut. Science, 322, 1108-1109.

Jouquet, P., Ranjard, L., Lepage, M. \& Lata, J.C. (2005). Incidence of fungus-growing termites (Isoptera, Macrotermitinae) on the structure of soil microbial communities. Soil Biol. , 37, 1852-1859.

Jouquet, P., Traoré, S., Choosai, C., Hartmann, C. \& Bignell, D. (2011). Influence of termites on ecosystem functioning. Ecosystem services provided by termites. Eur. J. Soil Biol. , 47, 215-222.

Kirker, G.T., Wagner, T.L. \& Diehl, S. V. (2012). Relationship between wood-inhabiting fungi and Reticulitermes spp. in four forest habitats of northeastern Mississippi. Int. Biodeterior. Biodegradation , 72, $18-25$.

Köhler, T., Dietrich, C., Scheffrahn, R.H. \& Brune, A. (2012). High-resolution analysis of gut environment and bacterial microbiota reveals functional compartmentation of the gut in wood-feeding higher termites (Nasutitermes spp.). Appl. Environ. Microbiol. , 78, 4691-4701.

Krishna, K., Grimaldi, D.A. \& Engel, M.S. (2013). Treatise on the Isoptera of the World: Vol. 1. Bull. Am. Museum Nat. Hist. , 377, 1-196.

Legendre, P. \& Gallagher, E.D. (2001). Ecologically meaningful transformations for ordination of species data. Oecologia , 129, 271-280.

Legendre, P. \& Legendre, L. (2012). Numerical Ecology . third edit. Elsevier, Amsterdam and Oxford. 
Makonde, H.M., Mwirichia, R., Osiemo, Z., Boga, H.I. \& Klenk, H.P. (2015). 454 pyrosequencing-based assessment of bacterial diversity and community structure in termite guts, mounds and surrounding soils. Springerplus $, 4,471$.

Manjula, A., Pushpanathan, M., Sathyavathi, S., Gunasekaran, P. \& Rajendhran, J. (2016). Comparative analysis of microbial diversity in termite gut and termite nest using ion sequencing. Curr. Microbiol. , 72, $267-275$.

Martínez Arbizu, P. (2017). pairwiseAdonis: pairwise multilevel comparison using Adonis.

Mikaelyan, A., Dietrich, C., Kohler, T., Poulsen, M., Sillam-Dussès, D. \& Brune, A. (2015). Community structure in the guts of higher termites. Mol. Ecol. , 24, 5284-5295.

Mikaelyan, A., Strassert, J.F.H., Tokuda, G. \& Brune, A. (2014). The fibre-associated cellulolytic bacterial community in the hindgut of wood-feeding higher termites (Nasutitermes spp.). Environ. Microbiol. , 16, $2711-2722$.

Mossebo, D.C., Essouman, E.P.F., Machouart, M.C. \& Gueidan, C. (2017). Phylogenetic relationships, taxonomic revision and new taxa of Termitomyces (Lyophyllaceae, Basidiomycota) inferred from combined nLSUand mtSSU-rDNA sequences. Phytotaxa, 321, 71-102.

Nobre, T., Koné, N. a, Konaté, S., Linsenmair, K.E. \& Aanen, D.K. (2011). Dating the fungus-growing termites' mutualism shows a mixture between ancient codiversification and recent symbiont dispersal across divergent hosts. Mol. Ecol. , 20, 2619-2627.

Noda, S., Ohkuma, M., Yamada, A., Hongoh, Y. \& Kudo, T. (2003). Phylogenetic position and in situ identification of ectosymbiotic spirochetes on protists in the termite gut. Appl. Environ. Microbiol. , 69, 625-633.

Noirot, C. \& Darlington, J.P.E.C. (2000). Termite nests: architecture, regulation and defence. In: Termites: Evolution, Sociality, Symbioses, Ecology (eds. Abe, T., Bignell, D.E. \& Higashi, M.). Kluwer Academic Publishers, Dordrecht, The Netherlands, pp. 121-139.

Oksanen, J., Kindt, R., Legendre, P., O'Hara, B., Simpson, G.L., Solymos, P., et al. (2007). The vegan package. Community Ecol. Packag. , 10, 631-637.

Otani, S., Hansen, L.H., Sørensen, S.J. \& Poulsen, M. (2016). Bacterial communities in termite fungus combs are comprised of consistent gut deposits and contributions from the environment. Microb. Ecol. , 16, 207-220.

Otani, S., Mikaelyan, A., Nobre, T., Hansen, L.H., Koné, N.G.A., Sørensen, S.J., et al. (2014). Identifying the core microbial community in the gut of fungus-growing termites. Mol. Ecol. , 23, 4631-4644.

Rosengaus, R.B., Guldin, M.R. \& Traniello, J.F.A. (1998). Inhibitory effect of termite fecal pellets on fungal spore germination. J. Chem. Ecol. , 24, 1697-1706.

Rosengaus, R.B., Traniello, J.F.A. \& Bulmer, M.S. (2011). Ecology, behavior and evolution of disease resistance in termites. In:Biology of termites: A modern synthesis (eds. Bignell, D.E., Roisin, Y. \& Lo, N.). Springer, Dordrecht Heidelberg London New York, pp. 165-192.

Rosengaus, R.B., Mead, K., Du Comb, W.S., Benson, R.W. \& Godoy, V.G. (2013). Nest sanitation through defecation: Antifungal properties of wood cockroach feces. Naturwissenschaften , 100, 1051-1059.

Rouland-Lefèvre, C. (2000). Symbiosis with fungi. In: Termites: Evolution, Sociality, Symbioses, Ecology (eds. Abe, T., Bignell, D.E. \& Higashi, M.). Kluwer Academic Publishers, Dordrecht, The Nederlands, pp. 289-306.

Shinzato, N., Muramatsu, M., Watanabe, Y. \& Matsui, T. (2005). Termite-regulated fungal monoculture in fungus combs of a macrotermitine termite Odontotermes formosanus . Zoolog. Sci. , 22, 917-922. 
Stoddard, S.F., Smith, B.J., Hein, R., Roller, B.R.K. \& Schmidt, M. (2015). rrnDB: improved tools for interpreting rRNA gene abundance in bacteria and archaea and a new foundation for future development.Nucleic Acids Res. , 43, D593-D598.

Thomas, D., Vandegrift, R., Bailes, G., and Roy, B. (2017). Understanding and mitigating some limitations of Illumina(c) MiSeq for environmental sequencing of Fungi. bioRxiv, 184960.

Ulyshen, M.D. (2016). Wood decomposition as influenced by invertebrates.Biol. Rev. , 91, 70-85.

Ulyshen, M.D. \& Wagner, T.L. (2013). Quantifying arthropod contributions to wood decay. Methods Ecol. Evol. , 4, 345-352.

Ulyshen, M.D., Wagner, T.L. \& Mulrooney, J.E. (2014). Contrasting effects of insect exclusion on wood loss in a temperate forest.Ecosphere, 5, 47.

Van Rhijn, P. \& Vanderleyden, J. (1995). The Rhizobium -plant symbiosis. Microbiol. Rev. , 59, 124-142.

Větrovský, T. \& Baldrian, P. (2013). The variability of the $16 \mathrm{~S}$ rRNA gene in bacterial genomes and its consequences for bacterial community analyses. PLoS One, 8, e57923.

Větrovský, T., Baldrian, P. \& Morais, D. (2018). SEED 2: a user-friendly platform for amplicon highthroughput sequencing data analyses. Bioinformatics , 34, 2292-2294.

Visser, A.A., Nobre, T., Currie, C.R., Aanen, D.K. \& Poulsen, M. (2012). Exploring the potential for Actinobacteria as defensive symbionts in fungus-growing termites. Microb. Ecol. , 63, 975-985.

Wang, Q., Garrity, G.M., Tiedje, J.M. \& Cole, J.R. (2007). Naive Bayesian classifier for rapid assignment of rRNA sequences into the new bacterial taxonomy. Appl. Environ. Microbiol. , 73, 5261-5267.

Wood, T. G. \& Sands, W.A. (1978). The role of termites in ecosystems. In: Production Ecology of Ants and Termites (ed. Brian, M.V.). Cambridge University Press, Cambridge, UK, pp. 245-292.

Table 1 Results of the pairwise PERMANOVA analysis.

Table S1 Taxonomy and abundance of the bacterial OTUs identified by the Partial Redundancy analysis represented in Figure 2.

\section{Hosted file}

image1. emf available at https://authorea.com/users/307692/articles/438707-termites-are-associatedwith-external-species-specific-bacterial-communities

Figure 1 Non-metric multidimensional scaling of bacterial communities associated with the bodies and galleries of the termites Coptotermes testaceus, Heterotermes tenuis andNasutitermes octopilis, and with wood controls.

\section{Hosted file}

image2.emf available at https://authorea.com/users/307692/articles/438707-termites-are-associatedwith-external-species-specific-bacterial-communities

Figure 2 Partial redundancy analysis of bacterial communities associated with termite bodies and galleries and with wood controls. (A) Coptotermes testaceus, (B) Heterotermes tenuis, (C)Nasutitermes octopilis . Taxonomic identification of OTUs is provided in Table S1.

\section{Hosted file}

Table 1.xlsx available at https://authorea.com/users/307692/articles/438707-termites-are-associatedwith-external-species-specific-bacterial-communities

\section{Hosted file}


Table S1.xlsx available at https://authorea.com/users/307692/articles/438707-termites-are-associatedwith-external-species-specific-bacterial-communities 